ISPEC Tarım Bilimleri Dergisi

$2020: 4(2)$

(C) Telif hakk ISPEC'e aittir

Arastırma Makalesi

\section{*Erdal KARADENIZ}

Orcid No: 0000-0001-6873-7066

\section{**Abdullah EREN}

Orcid No: 0000-0003-1187-7978

\section{***Veysel SARUHAN}

Orcid No: 0000-0002-4906-8917

*Kızlltepe Meslek Yüksek Okulu

Bitkisel ve Hayvansal Üretim

Bölümü, Sulama Teknolojisi

Programı (Sorumlu yazar)

erdalkaradeniz@artuklu.edu.tr

**Kızıltepe Meslek Yüksek Okulu

Bitkisel ve Hayvansal Üretim

Bölümü, Organik Tarım

Program1,

***Dicle Üniversitesi Ziraat Fakültesi

Tarla Bitkileri Bölümü

vsaruhan@hotmail.com

DOI

https://doi.org/10.46291/ISPECJASv ol4iss2pp114-124

Geliş Tarihi: $\quad 10 / 04 / 2020$

Kabul Tarihi: 27/05/2020

\section{Anahtar Kelimeler}

Silaj kalitesi, ADF, NDF, karışım

\section{Keywords}

Silage quality, ADF, NDF, mixed

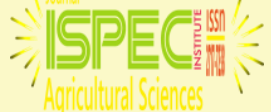

www.ispecjournal.com
Mürdümük (Lathyrus sativus L.) ve Tritikale (xTriticosecale Wittmack) Karışımlarının Silaj Kalitesinin Belirlenmesi

\section{Özet}

$\mathrm{Bu}$ çalışmada, Mardin ili Kızıltepe ilçesi ekolojik koşullarında, sulu şartlarda yetiştirilen Mürdümük (Lathyrus sativus L.) ile Tritikale (xTriticosecale Wittmack) hasıllarının farklı oranlarda karıştırılması ile elde edilen silajların kalite özelliklerinin araştırılması amaçlanmıştır. Kızıltepe ilçesi Köprübaşı Mahallesi çiftçi arazisinde 2016-2017 ve 2017 2018 yetiştirme sezonun yürütülen bu çalışmada bitki materyali olarak GAP Mavisi mürdümük çeşidi ile Tatlıcak-97 tritikale çeşidi kullanılmıştır. Çalışmada $\% 100$ mürdümük, $\% 100$ tritikale, $\% 80$ mürdümük $+\% 20$ tritikale, $\% 60$ mürdümük $+\% 40$ tritikale, $\% 40$ mürdümük $+\% 60$ tritikale, $\% 20$ mürdümük $+\% 80$ tritikale karışım oranları kullanılmıştır. Silajlanacak materyal, gofrajlı vakum poşetlerine 1 kg'lık karışımlar halinde konularak lavion marka vakum makinesi ile içinde hava kalmayacak şekilde 3 tekerrür olarak hazırlanıp vakumlanmıştır. Vakumlanmış poşetler 45 gün sonra açılarak fiziksel (renk, koku ve strüktür) ve kimyasal (silaj pH değeri, ADF, NDF, ham protein, ham kül, kuru madde ve laktik asit oranları) özellikleri incelenmiştir. Fiziksel özellikler bakımından nitelik sınıfı en yüksek \%100 tritikale silajından elde edilmiştir. Kimyasal özellikler açısından bakıldığında; $\mathrm{pH}$ değeri için $\% 100$ tritikale silajı, kuru madde oranı $\% 100$ tritikale silaj1, ADF oranı $\% 100$ mürdümük silaj1, NDF oranı $\% 100$ mürdümük silaj1, ham protein $\% 100$ mürdümük silaj1, ham kül $\% 100$ tritikale silajı, fleig puanı ise $\% 100$ tritikale silajından elde edilmiştir. Tüm analiz sonuçları incelendiğinde farklı oranlarda karıştırılan Mürdümük+Tritikale silajı için $\% 80$ mürdümük $+\% 20$ tritikale silaj karışımı uygun bulunmuştur.

Determination of Silage Quality of Grasspea (Lathrus sativus L.) and Triticale (xTriticosecale Wittmack) Mixtures

\section{Abstract}

The aim of thisstudywas to investigate the quality characteristics of silage obtained by mixing Grasspea (Lathyrus sativus L.) and Tritikale (xTriticosecale Wittmack) yields in different ratios under the ecological conditions in Kiziltepe district of Mardin province. Field experiments were carried out in the 2016-2017 and 2017-2018 growing seasons in the farminglands of Kiziltepe district, mainly in Koprubasi village. "GAP Blue" grasspea variety and "Tatlicak-97"triticale variety were used as material. Mix ratios of $100 \%$ grasspea, $100 \%$ triticale, $80 \%$ grasspea + $20 \%$ triticale, $60 \%$ grasspea $+40 \%$ triticale, $40 \%$ grasspea $+60 \%$ triticale, $20 \%$ grasspea $+80 \%$ triticale were used in the study. The material to be silage was placed in embossed vacuum bags in $1 \mathrm{~kg}$ mixtures and prepared in 3 replications with a lavion vacuum machine so that there was no air inside. Vacuumed bags were opened 45 days later and physical (color, odour and structure) and chemical (silage $\mathrm{pH}$ value, ADF, NDF, crude protein, crude ash, dry matter and lactic acid ratios) analyses were made. In terms of physical properties, the highest quality class was obtained from the $100 \%$ triticale silage. In terms of chemical properties; desired results were obtained from $100 \%$ triticale silage (for $\mathrm{pH}$ value and dry matter rate), $100 \%$ grasspea silage (for ADF rate, NDF rate raw protein), $100 \%$ triticale silage (for raw ash and fleig score). The results of our study indicated that $80 \%$ grasspea $+20 \%$ triticale silage mixture 


\section{GİRIŞ}

Türkiye'nin hemen her bölgesinde görülebilen mürdümük, daha çok Doğu ve Güney Doğu Anadolu belgesinde yayılış göstermektedir (Genç ve Şahin, 2001). Tarımsal açıdan önemli bir tür olan yaygın mürdümük (Lathyrus sativus L.) yeşil yem ve kuru ot olarak birçok çiftlik hayvanı tarafından tüketilmekle birlikte daha çok küçükbaş hayvanlar tarafından tercih edilmektedir. Türkiye'de çayır ve mera alanlarının ihtiyacı karşılamaktan uzak oluşu ve yetersiz kaba yem üretimi sorunu karşısında silaj teknolojisi önemli bir alternatif oluşturmaktadır. $\mathrm{Bu}$ yöntem ile, yemlerin tazeliklerini koruyarak uzun süre saklanabilmesi nedeniyle hayvan beslemede gereksinim duyulan kaba yem ihtiyacı yılın her döneminde karşılanabilmektedir (Kutlu ve ark., 2005). Silaj yapmak amaciyla bitkiler tek, ikili veya daha fazla türün karıştırılmasıyla ekilebilmektedir. Farklı türlerin karıştırılarak ekilmesi halinde, verim ve kalitede artış, hasat kolaylığı ve baklagiller gibi bazı türlerin tek başına silolanmasında karşılaşılan sorunların bertaraf edilmesi mümkün olmaktadır. Baklagillerin gövde yapısı zayıf olduğu için yatmaya meyillidirler. Baklagillerin bu tür dezavantajlarını ortadan kaldırmak için tahıllarla karışık ekilmesi gerekmektedir. Karışık ekimde baklagiller tahıllara sarılarak daha iyi gelişmekte, azot fiksasyonu yaparak da tahılların daha iyi gelişmesini teşvik etmektedir. Böylece daha kaliteli ve yüksek verim elde edilebilmektedir (Anlarsalve ark., 1996; Tan ve Serin, 1996). Protein oranı yüksek, karbonhidrat oranı düşük olan baklagillerden yapılan silajlarda istenilen sonuçlar alınamamaktadır. Ancak baklagillerin, nişasta içeriği yüksek arpa, yulaf ve tritikale gibi tahıllarla yapılan silajlarında istenilen nitelikte bir ürün elde etmek mümkündür (Goodrich ve Meiske, 1985).

$\mathrm{Bu}$ araştırmanın amacı, mürdümük ve tritikale hasıllarının farklı oranlarda karıştırılması ile yapılan silajların özelliklerinin araştırılması amaçlanmıştır.

\section{MATERYAL ve YÖNTEM}

Araştırma 2016-2017 (1.y1l) ve20172018 (2.y1l) yılları arasında Mardin ili Kızıltepe ilçesine bağlı Köprübaşı köyünde çiftçi arazisinde yürütülmüştür. Denemede, Tatlıcak-97 tritikale çeşidi (xTriticosecale Wittmack), GAP mavisi mürdümük (Lathyrus sativus L.) çeşidi kullanılmıştır. Tritikale çeşidinin özelliklerini bakıldığında, uzun boylu (110-120cm), başak rengi açık-kahverengi ve kılçıklıdır. 
Yatmaya dayanıklı sağlam bir sap yapısına sahiptir. Mürdümük çeşidi, hem yeşil hem de kuru ot olarak değerlendirilebilen, bitki boyu orta, çiçek rengi mavi, tek yıllık bir bitkidir. Mürdümük (M) ve tritikale (T) saf olarak birer parselde, markörle açılan sıralara elle ekilmiştir. Parseller, $20 \mathrm{~cm}$ sıra arası, 10 m uzunluk ve 20 sıradan oluşmuş olup her bir parsel alanı $40 \mathrm{~m}^{2}$, dir. Tritikale her iki yılda da dekara $25 \mathrm{~kg}$ tohum gelecek şekilde ekim yapılmış ve ekimle birlikte 3.6 $\mathrm{kg} / \mathrm{da} \mathrm{N}, 9.2 \mathrm{~kg} / \mathrm{da} \mathrm{P}_{2} \mathrm{O}_{5}$ ve üst gübre olarak da 4 kg/da N verilmiştir (Aydoğan ve ark., 2011). Mürdümük ise dekara $10 \mathrm{~kg}$ tohum gelecek şekilde ekimi yapılmış olup ekimle beraber $3.6 \mathrm{~kg} / \mathrm{da} \mathrm{N}$ ve $9.2 \mathrm{~kg} / \mathrm{da} \mathrm{P}_{2} \mathrm{O}_{5}$ verilmiştir (Tan ve Serin, 2013 ). Her iki yılda da tritikale süt olum döneminde, mürdümük ise çiçeklenme döneminde otlar biçilerek hasat yapılmıştır. Orakla hasat edilen tritikale ve mürdümük otları 3-4 saat gölgede soldurulduktan sonra traktörün kuyruk mili ile çalışan silaj makinası kullanılarak 05-1 cm'lik boyutlarda kıyılmıştır. Kıyılmış mürdümük ve tritikale, belirlenen oranlarda tartılarak karıştırılmış ve 1 kg'lık gofrajlı vakum poşetlerine konulmuştur. Poşetlerin içindeki hava tamamen alınana kadar vakumlanmış olup ağızları vakum makinası ile kaynak yapılarak kapatılmıştır. Karışım oranları (KO) \%100 T, \%100 M, \%80 M + \%20 T, $\% 60 \mathrm{M}+\% 40 \mathrm{~T}, \% 40 \mathrm{M}+\% 60 \mathrm{~T}, \% 20$ $\mathrm{M}+\% 80$ T'den oluşmuştur. Her bir uygulamadan 3 tekerrür olmak üzere toplam 18 poşet hazırlanmıştır. Hazırlanan poşetler karanlık ortamda mayalanmak üzere 45 gün bekletilmiştir. 45 gün sonunda olgunlaşan silajlar açılarak gerekli fiziksel ve kimyasal analizler yapılmıştır.

\section{Fiziksel Gözlemler}

45 günlük mayalanma sürecinden sonra açılan silaj poşetlerinden alınan numuneler üzerinde, fiziksel analizler Alman tarım Örgütü (DLG) standartlarına göre; renk (02 puan), yapı (0-4 puan), koku (0-14 puan) yapılmıştır. Fiziksel analizde her parametre beş kişi tarafından sübjektif olarak incelenmiş ve bu verilere ait ortalama puan hesaplanmıştır (Çizelge-1). Daha sonra laboratuvarda elde edilen $\mathrm{pH}$ ve kuru madde oranları kullanılarak Fleig puanları (Denklem 1) hesaplanmıştır (Kılıç, 1986). Fleig Puanı $=220+(2 \times$ \% Kuru Madde-15) $(40 \times \mathrm{pH})$ Denklem 1. 
Çizelge 1. Alman Tarım Örgütü (DLG) tarafından geliştirilen fiziksel değerlendirme anahtarı

\begin{tabular}{ll}
\hline Koku & Puan \\
\hline Tereyă̆ asidi kokusu yok, hafif ekşimsi, meyvamsı ve aromatik koku & 14 \\
Az miktarda tereyağ asidi,kuvvetli ekşi ve hafif kızışma & 8 \\
Orta derecede tereyağ asidi kokusu, kuvvetli kızışa-küf kokusu & 4 \\
Kuvvetli tereyağ asidi kokusu veya amonyak kokusu, çok hafif ekşi koku & 2 \\
Kuvvetli çürük, amonyak veya küf kokusu & 0 \\
\hline Dış Görünüş (Yapı) & \\
\hline Yaprak ve sapların yapısıı bozulmamış & 2 \\
Yaprakların yapısı biraz bozulmuş & 1 \\
Yaprak ve sapların yapısı bozulmuş, küflü ve kirli & 0 \\
Yaprak ve sap çürümüşs & \\
\hline Renk & 2 \\
\hline Silolandığı andaki rengini koruyor(soldurulmuş silajda kahverengi) & 1 \\
Renk çok az değişmiş (sarıdan kahverengiye) & 0 \\
Renk tamamen değişmiş (küflü yeşili) & \\
\hline Nitelik sınıfi: 18-20 puan (çok iyi) 14-17 puan (iyi) & \\
10-13 puan (orta) 5-9 puan (düşük) 0-4 puan (bozulmuş) &
\end{tabular}

\section{Kimyasal işlemler}

Silaj örneklerinden 10 gr alınarak üzerine $90 \mathrm{ml}$ saf su eklenip iyice karıştırıldıktan sonra $\mathrm{pH}$ metre ile ölçülmüştür (Anonim, 1993 ). Silaj örnekleri 20-25 g'llk yaş örnekler halinde, kurutma dolabinda $105{ }^{\circ} \mathrm{C}^{\prime}$ de 24 saat kurutulduktan sonra hassas terazide tartılarak kuru madde oranları hesaplanmıştır (Neto ve ark., 2014). Kurutulan silaj örnekleri ögütülüp 1 mm'lik elekten geçirildikten sonra 3'er g alınarak porselen krozeye konulmuş ve 550-650 ${ }^{\circ} \mathrm{C}$ 'de 4 saat süreyle kül firınında yakılmıştır. Daha sonra hassas terazide tartılarak ham kül oranı hesaplanmıştır. Ögütülmüş silaj örneklerinden 1 'er $\mathrm{g}$ alınarak ADF ve NDF için ANKOM Fiber teknoloji yöntemine göre analizler yapılmış olup ADF ve NDF oranları hesaplanmıştır.
Ögütülmüş silaj örneklerinden $2 \mathrm{~g}$ alınarak Kjeldahl yönteminin uygulanması ile azot oranları belirlenmiș daha sonra belirlenen azot oranlarının 6.25 katsayısı ile çarpımı sonucu ham protein oranları hesaplanmıştır (Bremner, 1965). Laktik asit analizi yüksek performanslı sivi kromatografi (HPLC) cihazı ile yapılmıştır.

\section{Verilerin Değerlendirilmesi}

Elde edilen sonuçlar tesadüf parselleri deneme desenine göre varyans analizi JUMP istatistik paket programı kullanılmıştır (Kalaycı, 2005).

\section{BULGULAR ve TARTIŞMA}

Çizelge 2'de mürdümük ve tritikalenin yalın ve farklı miktarlarda karıştırılması ile elde edilen silaj örneklerinin fiziksel gözlem değerleri (renk, koku ve strüktür) ve bunlara ait puanlar ve nitelik sınıflarına ait değerler verilmiştir. Her iki yılda da toplam 
puanlar incelendiğinde en yüksek puanların, koku ve renk özellikleri \%100T (1. y1l 20 puan ve 2. y1l 18 puan) silajından elde edilmiş olup, karışımdaki tritikale oranı artıkça toplam puan da $\operatorname{arttığ1}$ görülmektedir.

Çizelge 2. Silajların fiziksel özellikleri, puanlaması ve kalite sınıfları

\begin{tabular}{|c|c|c|c|c|c|c|c|c|}
\hline & & & & 1. $\mathrm{y}_{1}$ & & & & \\
\hline KO & Koku & Puan & Strüktür & Puan & Renk & Puan & Top. & Nit. Snf. \\
\hline$\% 100 \mathrm{M}$ & Kuvvetli ekşi & 8 & Hafif küflü & 1 & Kahve-yeşil & 1 & 11 & Orta \\
\hline$\% 100 \mathrm{~T}$ & Kuvvetli ekşi & 14 & Değişmemiş & 4 & Zeytin yeşili & 2 & 20 & Çok İyi \\
\hline$\% 80 \mathrm{M}+\% 20 \mathrm{~T}$ & Kuvvetli ekşi & 10 & Hafif küflü & 1 & Kahve-yeşil & 1 & 12 & Orta \\
\hline$\% 60 \mathrm{M}+\% 40 \mathrm{~T}$ & Kuvvetli ekşi & 10 & Değişmemiş & 2 & Kahve-yeşil & 1 & 13 & Orta \\
\hline$\% 40 \mathrm{M}+\% 60 \mathrm{~T}$ & Kuvvetli ekşi & 13 & Değişmemiş & 2 & Zeytin yeşili & 1 & 15 & İyi \\
\hline$\% 20 \mathrm{M}+\% 80 \mathrm{~T}$ & Kuvvetli ekşi & 13 & Değişmemiş & 3 & Zeytin yeşili & 2 & 18 & Çok İyi \\
\hline & \multicolumn{8}{|c|}{ 2.y1l } \\
\hline$\% 100 \mathrm{M}$ & Kuvvetli ekşi & 10 & Hafif küflü & 1 & Kahve-yeşil & 1 & 12 & Orta \\
\hline$\% 100 \mathrm{~T}$ & Kuvvetli ekşi & 13 & Değişmemiş & 3 & Zeytin yeşili & 2 & 18 & Çok İyi \\
\hline$\% 80 \mathrm{M}+\% 20 \mathrm{~T}$ & Kuvvetli ekşi & 10 & Hafif küflü & 1 & Kahve-yeşil & 1 & 12 & Orta \\
\hline$\% 60 \mathrm{M}+\% 40 \mathrm{~T}$ & Kuvvetli ekşi & 10 & Değişmemiş & 1 & Kahve-yeşil & 1 & 12 & Orta \\
\hline$\% 40 \mathrm{M}+\% 60 \mathrm{~T}$ & Kuvvetli ekşi & 12 & Değişmemiş & 2 & Zeytin yeşili & 2 & 16 & İyi \\
\hline$\% 20 \mathrm{M}+\% 80 \mathrm{~T}$ & Kuvvetli ekşi & 12 & Değişmemiş & 4 & Zeytin yeşili & 2 & 18 & Çok İyi \\
\hline
\end{tabular}

Çizelge 2'de 1. y1l en düşük toplam (8 koku ve 11 renk) puan \%100 mürdümük silajından elde edilmiştir. Ayrıca, tritikale oranlarının artması ile genel olarak renk ve koku özelliklerinin iki yıl ortalama puanlarda da artış olduğu belirlenmiştir.
$\mathrm{Bu}$ durum baklagil ve buğdaygil bitkilerin karışım silajında, daha narin yapıya sahip olan baklagillerin gerek renk ve gerekse strüktür olarak kolaylıkla bozulduğunu Bulgurlu ve Ergül (1978), tarafından belirtilmiştir.

Çizelge 3. Silaj pH değerleri ve kuru madde miktarları

\begin{tabular}{|c|c|c|c|c|c|c|}
\hline \multicolumn{4}{|l|}{ Silaj pH Değeri } & \multicolumn{3}{|c|}{ Silaj Kuru madde Miktarı (\%) } \\
\hline Uygulama & 1. Y1l & 2. Yil & Ort. & 1. y1l & 2.y1l & Ort. \\
\hline$\% 100 \mathrm{M}$ & $4.28 \mathrm{ab}$ & $4.42 \mathrm{a}$ & $4.35 \mathrm{a}$ & $29.7 \mathrm{a}$ & $27.4 \mathrm{e}$ & $28.5 \mathrm{~d}$ \\
\hline$\% 100 \mathrm{~T}$ & $3.92 \mathrm{c}$ & $3.98 \mathrm{c}$ & $3.95 \mathrm{c}$ & $33.6 \mathrm{a}$ & $32.9 \mathrm{ab}$ & $33.3 \mathrm{a}$ \\
\hline$\% 20 \mathrm{M}+\% 80 \mathrm{~T}$ & $3.93 \mathrm{c}$ & $4.05 \mathrm{bc}$ & $3.99 \mathrm{c}$ & $31.9 \mathrm{bc}$ & $32.8 \mathrm{ab}$ & $32.4 \mathrm{a}$ \\
\hline$\% 40 \mathrm{M}+\% 60 \mathrm{~T}$ & $3.99 \mathrm{c}$ & $4.07 \mathrm{bc}$ & $4.03 \mathrm{bc}$ & $29.8 \mathrm{~d}$ & $32.3 \mathrm{ab}$ & $31.4 \mathrm{~b}$ \\
\hline$\% 60 \mathrm{M}+\% 40 \mathrm{~T}$ & $4.01 \mathrm{c}$ & $4.07 \mathrm{bc}$ & $4.04 \mathrm{bc}$ & $30.2 \mathrm{~d}$ & $29.7 \mathrm{~d}$ & $29.9 \mathrm{c}$ \\
\hline$\% 80 \mathrm{M}+\% 20 \mathrm{~T}$ & $4.13 \mathrm{bc}$ & $4.25 \mathrm{ab}$ & $4.19 \mathrm{ab}$ & $30.3 \mathrm{~d}$ & $30.8 \mathrm{~cd}$ & $30.6 \mathrm{bc}$ \\
\hline Ort. & $4.04 \mathrm{~b}$ & $4.14 \mathrm{a}$ & & $30.9 \mathrm{a}$ & $31.1 \mathrm{a}$ & \\
\hline Y1l (Lsd) & & $0.095 *$ & & & Ö.D. & \\
\hline Uyg (Lsd) & & $0.164 * *$ & & & $0.91 * *$ & \\
\hline Y11*Uyg (Lsd) & & $0.234 * *$ & & & $1.29 * *$ & \\
\hline $\mathrm{CV}(\%)$ & & 3.37 & & & 2.46 & \\
\hline
\end{tabular}


Silaj pH değeri karışım oranları 2 yıllık ortalamalar arasında yıllar $\mathrm{P}<0.05$ oranında, y1llar $\mathrm{x}$ uygulama interaksiyonu ise $\mathrm{P}<0.01$ oranında istatistiksel olarak önemli bulunmuştur. İki yıllık birleştirilmiş ortalamalara göre silaj pH değeri en yüksek (4.35) \%100 mürdümük uygulamasından, en düşük ise (3.95) \%100 tritikale silajından elde edilmiştir. Silaj kuru madde oranının iki yıllık ortalamaları incelendiğinde uygulamaların yıllar üzerinde bir etkisi olmadığ 1 ve istatiksel olarak önemsiz olduğu, uygulama ile yıllar x uygulamalar interaksiyonu ise istatiksel olarak $\mathrm{P}<0.01$ oranında önemli olduğu belirlenmiştir. Kuru madde miktarı en yüksek (\%33.3) tritikale silajının \%100'lük uygulamasından, en düşük ise (\%28.5) ile $\% 100 \mathrm{M}$ uygulamasından elde edilmiştir.
Mürdümük oranlarının artması ile silaj pH değerinde artış olurken, kuru madde miktarında ise azalma olduğu belirlenmiştir (Çizelge 3).

Kaliteli bir silaj elde etmek için silaj pH seviyesinin düşük seviyelerde tutulması gerekmektedir (Liu ve ark., 2013). Bir çok araştırmacı tarafından silaj pH değerinin 3.5 ile 4.5 arasında olmasının uygun değerler olduğu, Geren (2014) tarafindan belirtilmiştir. Fermantasyon kalitesini belirleyen ve yemlerin en uygun düzeyde ekşiyip ekşimediklerini belirme amacıyla silaj $\mathrm{pH}$ değerleri kullanılmaktadır. Kuru madde içeriği bitkinin farklı olgunluk dönemlerinde hasat edildiği zaman silaj kalitesinde değişim gösterdiği Filya (2002) tarafından bildirilmiştir.

Çizelge 4. Silaj ADF ve NDF oranları

\begin{tabular}{|c|c|c|c|c|c|c|}
\hline & \multicolumn{3}{|c|}{ Silaj ADF (\%) oranı } & \multicolumn{3}{|c|}{ Silaj NDF (\%) oranı } \\
\hline $\mathrm{KO}$ & 1.y1l & 2.y1l & Ort. & 1.y1l & 2.y1l & Ort. \\
\hline$\% 100 \mathrm{M}$ & 33.23 be & $31.58 \mathrm{e}$ & $32.41 \mathrm{~d}$ & $44.31 \mathrm{~g}$ & $45.85 \mathrm{fg}$ & $45.08 \mathrm{~d}$ \\
\hline$\% 100 \mathrm{~T}$ & $34.52 \mathrm{ab}$ & $33.46 \mathrm{bd}$ & $33.99 \mathrm{ab}$ & $50.12 \mathrm{~b}$ & $52.36 \mathrm{a}$ & $51.24 \mathrm{a}$ \\
\hline$\% 20 \mathrm{M}+\% 80 \mathrm{~T}$ & $34.02 \mathrm{ac}$ & $35.24 \mathrm{a}$ & $34.63 \mathrm{a}$ & $49.3 \mathrm{bd}$ & $50.1 \mathrm{~b}$ & $49.70 \mathrm{~b}$ \\
\hline$\% 40 \mathrm{M}+\% 60 \mathrm{~T}$ & 32.82 be & 33.08 be & $32.95 \mathrm{bd}$ & 48.82 be & $49.56 \mathrm{bc}$ & $49.19 b$ \\
\hline$\% 60 \mathrm{M}+\% 40 \mathrm{~T}$ & $35.21 \mathrm{a}$ & 32.73 ce & $33.97 \mathrm{ac}$ & $47.18 \mathrm{df}$ & 46.72 ef & $46.95 \mathrm{c}$ \\
\hline$\% 80 \mathrm{M}+\% 20 \mathrm{~T}$ & $33.64 \mathrm{ac}$ & $31.88 \mathrm{de}$ & $32.76 \mathrm{~cd}$ & $46.2 \mathrm{fg}$ & $47.54 \mathrm{cf}$ & $46.87 \mathrm{c}$ \\
\hline ORT & $33.91 \mathrm{a}$ & $33 \mathrm{~b}$ & & $47.66 \mathrm{~b}$ & $48.69 \mathrm{a}$ & \\
\hline LSD (YIL) & \multicolumn{3}{|c|}{$0.70^{*}$} & \multicolumn{3}{|c|}{$0.89 *$} \\
\hline $\mathrm{LSD}(\mathrm{KO})$ & \multicolumn{3}{|c|}{$1.22 * *$} & \multicolumn{3}{|c|}{$1.53 *$} \\
\hline LSD (KOxYIL) & \multicolumn{3}{|c|}{$1.74 *$} & \multicolumn{3}{|c|}{ Ö.D. } \\
\hline $\mathrm{CV}(\%)$ & \multicolumn{3}{|c|}{3.06} & \multicolumn{3}{|c|}{2.64} \\
\hline
\end{tabular}

Çizelge 4'te ADF oranı 2 yıllık ortalama değerlere göre, y1l ile karışım oranı x y1l interaksiyonu $\mathrm{P}<0.05, \quad$ karışım oranı bakımından ise $\quad \mathrm{P}<0.01 \quad$ oranında 
istatistiksel olarak önemli bulunmuştur. Çizelge 4.'te silaj ADF oranı 2 yıl ortalamaları içerisinde en yüksek \%34.63 oranı $\% 20 \mathrm{M}+\% 80 \mathrm{~T}$, en düşük ise $\% 32.41$ ile \%100M'den elde edilmiştir. Silaj NDF karışım oranlarında yıllar ile karışım oranlarının istatiksel olarak $\mathrm{P}<0.05$ oranında önemli olduğu ve en yüksek NDF oran1 \%51.24 ile \%100T'den, en düşük ise \% 45.08 ile \%100M'den elde edilmiştir. ADF, NDF içerisinden hemiselülozun çıkartılmasından sonra kalan kısım olarak bilinmektedir (Budak ve Budak 2014).
Ayrıca, bitkilerde lif oranı olup, ADF oranı arttıkça otun sindirim oranı ve besin alımı düşmektedir, bundan dolayı ot kalitesinde önemli bir parametredir (Carr ve ark. 2004). Karışımlardaki tahıl miktarının artması ile beraber NDF oranının da arttığını Ross ve ark. (2004), tarafından belirtilmiştir. Karışımlarda yer alan baklagil bitkilerinin oranı artıkça ADF ve NDF oranı benzer şekilde azalmalar olduğu (Seydoşoğlu ve Gelir, Seydoşoğlu, 2019a, b; 2019; Turan 2019) tarafından belirtilmiştir.

Çizelge 5. Silaj ham protein ve ham kül oranları

\begin{tabular}{|c|c|c|c|c|c|c|}
\hline & Ham prot & $\operatorname{ran} 1(\%)$ & & Ham kü & $\%)$ & \\
\hline $\mathrm{KO}$ & 1.y1l & 2.y1l & ort. & 1.y1l & 2.y1l & ort. \\
\hline$\% 100 \mathrm{M}$ & $24.92 \mathrm{~s}$ & $23.56 \mathrm{a}$ & $24.24 \mathrm{a}$ & $8.25 \mathrm{ab}$ & $8.45 \mathrm{a}$ & $8.35 \mathrm{a}$ \\
\hline$\% 100 \mathrm{~T}$ & $8.25 \mathrm{~h}$ & $9.97 \mathrm{~g}$ & $9.11 \mathrm{f}$ & $5.63 \mathrm{~g}$ & $5.15 \mathrm{~h}$ & $5.39 \mathrm{f}$ \\
\hline$\% 20 \mathrm{M}+\% 80 \mathrm{~T}$ & $12.94 \mathrm{f}$ & $13.82 \mathrm{f}$ & $13.38 \mathrm{e}$ & $5.85 \mathrm{~g}$ & $5.63 \mathrm{~g}$ & $5.74 \mathrm{e}$ \\
\hline$\% 40 \mathrm{M}+\% 60 \mathrm{~T}$ & $16.31 \mathrm{e}$ & $15.27 \mathrm{e}$ & $15.79 \mathrm{~d}$ & $6.92 \mathrm{ef}$ & $6.72 \mathrm{f}$ & $6.82 \mathrm{~d}$ \\
\hline$\% 60 \mathrm{M}+\% 40 \mathrm{~T}$ & $18.72 \mathrm{~d}$ & $19.64 \mathrm{~cd}$ & $19.18 \mathrm{c}$ & $7.32 \mathrm{~d}$ & $7.1 \mathrm{de}$ & $7.21 \mathrm{c}$ \\
\hline$\% 80 \mathrm{M}+\% 20 \mathrm{~T}$ & $21.02 \mathrm{bc}$ & $21.58 \mathrm{~b}$ & $21.3 \mathrm{~b}$ & $7.82 \mathrm{c}$ & $7.96 \mathrm{bc}$ & $7.89 \mathrm{~b}$ \\
\hline ORT & $17.03 \mathrm{a}$ & $17.31 \mathrm{a}$ & & $6.96 \mathrm{a}$ & $6.84 \mathrm{a}$ & \\
\hline LSD (YIL) & & Ö.D. & & & Ö.D. & \\
\hline $\mathrm{LSD}(\mathrm{KO})$ & & $1.01 * *$ & & & $0.27 * *$ & \\
\hline LSD (KOxYIL) & & $1.43 *$ & & & Ö.D. & \\
\hline $\mathrm{CV}(\%)$ & & 4.9 & & & 3.2 & \\
\hline
\end{tabular}

Ham protein oranı ortalamaları içerisinde karışım oranları (KO) istatiksel olarak $\mathrm{P}<0.01$, karışım oranı $\mathrm{x}$ yıllar interaksiyonu bakımından $\mathrm{P}<0.05$, ham kül oranı bakımından ise sadece karışım oranları (KO) $\mathrm{P}<0.01$ oranında önemli bulunmuştur. Ham protein oranı karışım oranları içerisinde en yüksek (\%24.24)
$\% 100 \mathrm{M}$, en düşük (\%13.38) ise \%20M+\%80T karışımlarından elde edilmiştir. Ham kül oranı ortalamalar arasında en yüksek (\%8.35) ile \%100M, en düşük (\%5.39) ise \%100T'den elde edilmiştir (Çizelge 5). Baklagil ve buğdaygil bitkilerinin karışımlarından elde edilen silajlarda, karışımlardaki baklagil 
oranının artmasıyla ham protein miktarının da arttığını bildirmişlerdir (Geren ve ark., 2008). Baklagil bitkilerinin lif miktarı buğdaygil bitkilerindeki lif miktarından daha düşüktür (Önal-Aşçı ve Acar, 2018).

Çizelge 6. Silaj laktik asit oranı ve fleig puanı

\begin{tabular}{|c|c|c|c|c|c|c|}
\hline & \multicolumn{3}{|c|}{ Laktik asit oranı $(\%)$} & \multicolumn{3}{|c|}{ Fleig puanı } \\
\hline $\mathrm{KO}$ & 1.y1l & 2.y1l & ort. & 1.y1l & 2.y1l & ort. \\
\hline$\% 100 \mathrm{M}$ & $1.73 \mathrm{ef}$ & $1.69 \mathrm{f}$ & $1.71 \mathrm{~d}$ & $93.12 \mathrm{f}$ & $83.04 \mathrm{~g}$ & $88.08 \mathrm{e}$ \\
\hline$\% 100 \mathrm{~T}$ & $2.04 \mathrm{a}$ & $2.10 \mathrm{a}$ & $2.07 \mathrm{a}$ & $115.36 \mathrm{a}$ & $111.66 \mathrm{ab}$ & $113.5 \mathrm{a}$ \\
\hline$\% 20 \mathrm{M}+\% 80 \mathrm{~T}$ & $1.92 \mathrm{~b}$ & $1.88 \mathrm{bc}$ & $1.9 \mathrm{~b}$ & $111.6 \mathrm{ab}$ & $108.6 \mathrm{bc}$ & $110.1 \mathrm{ab}$ \\
\hline$\% 40 \mathrm{M}+\% 60 \mathrm{~T}$ & $1.83 \mathrm{~cd}$ & $1.79 \mathrm{de}$ & $1.81 \mathrm{c}$ & $105.06 \mathrm{~cd}$ & $108.1 \mathrm{bc}$ & $106.58 \mathrm{bc}$ \\
\hline$\% 60 \mathrm{M}+\% 40 \mathrm{~T}$ & $1.85 \mathrm{bd}$ & $1.87 \mathrm{bd}$ & $1.86 \mathrm{bc}$ & $104.73 \mathrm{~cd}$ & $101.62 \mathrm{de}$ & $103.17 \mathrm{c}$ \\
\hline$\% 80 \mathrm{M}+\% 20 \mathrm{~T}$ & $1.81 \mathrm{ce}$ & $1.79 \mathrm{de}$ & $1.80 \mathrm{c}$ & $100.38 \mathrm{de}$ & 96.64 ef & $98.51 \mathrm{~d}$ \\
\hline ORT & $1.86 \mathrm{a}$ & $1.85 \mathrm{a}$ & & $105.5 \mathrm{a}$ & $101.6 \mathrm{bc}$ & \\
\hline LSD (YIL) & \multicolumn{3}{|c|}{ Ö.D. } & \multicolumn{3}{|c|}{$2.44 * *$} \\
\hline LSD (KO) & \multicolumn{3}{|c|}{$0.06 * *$} & \multicolumn{3}{|c|}{$4.22 * *$} \\
\hline LSD (KOxYIL) & \multicolumn{3}{|c|}{ Ö.D. } & \multicolumn{3}{|c|}{ Ö.D. } \\
\hline $\mathrm{CV}(\%)$ & \multicolumn{3}{|c|}{2.75} & \multicolumn{3}{|c|}{3.4} \\
\hline
\end{tabular}

Çizelge 6'da karışım oranlarının laktik asit miktarı ve Fleig puanı üzerine etkisi $\mathrm{P}<0.01$ oranında önemli, karışım oranları $\mathrm{x}$ y1llar interaksiyonunda laktik asit miktarı ve Fleig puanında istatiksel olarak önemsiz, karışım oranlarının Fleig puanında yıllar üzerine etkisi ise $\mathrm{P}<0.01$ oranında önemli bulunmuştur. İki yıllık birleştirilmiş ortalamalar incelendiğinde, en yüksek \%2.07 laktik asit oranı \%100T silajından, en düşük $\% 1.71$ ise $\% 100$ mürdümük silajından elde edilmiştir. Flieg puanında iki y1llık ortalamalar içerisinde en yüksek 113.5 puanı ile \%100T silajından, en düşük 88.08 ise $\% 100 \mathrm{M}$ silajından elde edilmiştir. Laktik asit oranı silajlardaki mürdümük miktarı artması ile azalma olduğu (Seydoşoğlu, 2018) tarafından da ifade edilmiştir. Başaran ve ark. (2018), tarafından yapılan araştırmalar sonucu silajlarda tahılların laktik asit oranının yalın baklagillere göre daha yüksek olduğunu, Can ve ark. (2019) bildirmişlerdir.

\section{SONUÇ ve ÖNERÍLER}

Yapılan araştırmada, tahıl bitkisi olan tritikale ile baklagillerden olan mürdümük bitkisinin farklı karışım oranları ile elde edilen sonuçlar özellikle karışımda mürdümük miktarının artması ile beraber silajlarda laktik asit ve ADF değerlerinin azaldığı, ham protein miktarında ise artış olduğu sonucunda, birçok araştırmacı tarafından belirtildiği gibi silolarda istenilen bir durum olması nedeniyle çalışmaya alınan mürdümük ve tritikalenin pozitif yönde bir sonuç elde edildiği belirlenmiştir. 
Tüm sonuçları incelendiğinde farklı oranlarda karıştırılan mürdümük ve tritikale silajı için \%80 mürdümük $+\% 20$ tritikale silaj karışımı oranlarının uygun olduğu belirlenmiştir.

\section{KAYNAKLAR}

Anlarsal, A.E., Ülgen, A.C., Gök, M., Yücel, C., Çakır, B., Onaç, İ. 1996. Çukurova'da tek yıllık baklagil yem bitkisi+misır üretim sisteminde baklagillerin ot verimleri ile azot fiksasyonlarının saptanması ve misır üretiminde azot kullanımını azaltma olanakları. Türkiye 3. Çayır Mer'a ve Yembitkileri Kongresi, 17-19 Haziran 1996, Erzurum.

Anonim, 1993. Bestimmungdes pHWertes.In:Diechemischenuntersuchungenv onFuttermitteln. Teil 18 Silage. Abschnit18.1Bestimmungdes pH-Wertes. MethodenbuchBd. III., VDLUFAV Verlag, Darmstadt.

Aydoğan, S., Şahin, M., Göçmen, Akçacık, A., Ayranc1, R. 2011. Konya koşullarına uygun yüksek verimli ve kaliteli arpa genotiplerinin belirlenmesi. Selçuk Tarım ve G1da Bilimleri Dergisi 25(1): 1016.

Bremner, J.M. 1965. Methods of soilanalysispart 2. chemical and microbiologicalproperties. in ed. American
Society of Agronomy, Inc. Pub. Argon Series, No.9 Madison. Wisconsin, U.S.A.

Budak, F., Budak, F. 2014. Yem bitkilerinde kalite ve yem bitkileri kalitesini etkileyen faktörler. Türk Bilimsel Derlemeler Dergisi, 7(1): 01-06.

Bulgurlu, Ş., Ergül, M. 1978. Yemlerin fiziksel, kimyasal ve biyolojik analiz metotları. E Ü. Basımevi Yayın No: 127, İzmir, 176s.

Can, M., Kaymak, G., Gülümser, E., Acar, Z., Ayab, İ. 2019. Orman üçgülü yulaf karışımlarının silaj kalitesinin belirlenmesi. Anadolu Tarım Bilimleri Dergisi,34(3): 371-376.

Carr, P.M.,Horsley, R.D., Poland, W.W. 2004. Barley, Oat And Cereal-PeaMixtures As DrylandForages $\dot{n} n$ The Northern Great Plains. Agronomy Journal. 96(3): 677-684.

Genç, H., Şahin, A. 2001. Batı akdeniz ve güney ege bölgesinde yetişen bazı Lathyrus L. türleri üzerinde sito taksonomik araştırmalar. Süleyman Demirel Üniversitesi Fen Bilimleri Dergisi, 5(1): 98112.

Geren, H. 2014. Farklı oranlarda baklagil yembitkileri ile silolanan dev kralotu (Pennisetum hybridum)'nun bazı kalite özellikleri üzerine bir araştırma. Ege Üniversitesi Ziraat Fakültesi Dergisi, 51(2): 209-217. 
Geren,H., Avcioglu, R., Soya, H., Kir, B. 2008. Intercropping of cornwithcowpea and bean: biomassyield and silagequality, AfricanJournal of Biotechnology, 7(22): 4100-4104.

Goodrich, R.D.,Meiske, J.C. 1985. Corn and sorghumsilages. Forages: the science of grasslandagriculture / under the editorialauthorship of Maurice E. Heath, Robert F. Barnes, Darrel S. Metcalfe; with 107 additionalcontributingauthors. 4th ed. Ames, Iowa, U.S.A. Iowa StateUniversityPress p. 527-536.

Kalaycı, M. 2005. Örneklerle jump kullanımı ve tarımsal araştırma için varyans analizi modelleri, Anadolu Tarımsal Araştırma Enstitüsü Müdürlüğü Yayınları, yayın no:21.

Kilıç, A. 1986. Silo yemi öğretim, öğrenim ve uygulama önerileri. Bilgehan Basımevi, İzmir.

Kutlu, H.R., Görgülü, M., Çelik, L.B. 2005. Genel hayvan besleme ders notu. Çukurova Üniversitesi, Adana, 23-24.

Liu, Q.H., Shao, T., Zhang, J.G. 2013. Determination of aerobicdeterioration of cornstalksilagecausedbyaerobicbacteria. A nimal Feed Science and Technology, 183(3-4): 124-131.

Neto, A.M.B., Marques, L.G., Prado, M.M.,Sartori, D.J., 2014. Mass transfer in infrareddrying of gel-coatedseeds. Advanc Chem Eng Sci, 4, 39-48.

Önal Aşç1, Ö., Acar, Z. 2018. Kaba yemlerde kalite. TMMOB Ziraat Mühendisleri Odası Yayınları, 112 s, Ankara.

Ross, S.M., King, J.R., O’Donovan, J.T., Spaner, D. 2004. Foragepotential of 1ntercroppingberseemcloverwithbarley, oatortriticale. AgronomyJournal. 96: 10131020.

Seydoşoğlu, S. 2018. Farklı oranlarda karıştırılan yem bezelyesi (Pisum sativum L.) ve arpa (Hordeum vulgare L.) hâsıllarının silaj kalitesine etki eden organik asit oranlarının belirlenmesi. Anadolu I. Uluslararası Multidisipliner Çalışmalar Kongresi, 893-898.

Seydoşoğlu, S. 2019a. Effects of different mixture ratios of grass pea (Lathyrus sativus L.) and barley (Hordeum vulgare) on quality of silage. Legume Research, 42(5): 666-670.

Seydoşoğlu, S. 2019b. Farklı oranlarda karıştırılan yem bezelyesi (Pisum sativum L.) ve arpa (Hordeum vulgare L.) hâsıllarının silaj ve yem kalitesine etkisi. Ege Üniversitesi Ziraat Fakültesi Dergisi 56 (3):297-302.

Seydoşoğlu, S., Gelir, G. 2019. Farklı oranlarda karıştırılan mürdümük (Lathrus 
sativus L.) ve arpa (Hordeumvulgare L.) hâsıllarının silaj özellikleri üzerinde bir araştırma. Iğdır Üniversitesi Fen Bilimleri Enstitüsü Dergisi, 9(1): 397-406.

Tan, M., Serin, Y. 1996. Fiğ + tahıl karışımlarında karışım oranlar ve biçim zamanlarının makro besin elementi kompozisyonuna etkileri. Türkiye 3. Çayır Mer'a ve Yembitkileri Kongresi, 17-19 Haziran, Erzurum.
Tan, M., Serin, Y. 2013. Baklagil Yem Bitkileri. Atatürk Üniversitesi Ziraat Fakültesi Ders Yayınları No:190, 222s.

Turan, N. 2019. Macar fiği ile arpa yaş otunun farklı oranlarda karıştırılarak elde edilen silajın kimyasal kompozisyonu ve kalite parametrelerinin belirlenmesi. Avrupa Bilim ve Teknoloji Dergisi, (17): 787-793. 